\title{
EFEKTIVITAS METODE APLIKASI VAKSIN TRIVALEN UNTUK PENCEGAHAN PENYAKIT BAKTERI POTENSIAL PADA BUDIDAYA IKAN AIR TAWAR
}

\author{
Taukhid\#, Tuti Sumiati, dan Septyan Andriyanto \\ * Balai Penelitian Perikanan Budidaya Air Tawar dan Penyuluhan Perikanan \\ (Naskah diterima: 2 Januari 2018; Revisi final: 14 Februari 2018; Disetujui publikasi: 14 Februari 2018)
}

\begin{abstract}
ABSTRAK
Penelitian ini bertujuan untuk mendapatkan metode aplikasi vaksin trivalen yang memberikan level proteksi terbaik untuk pencegahan penyakit bakteri potensial; motile aeromonas septicemia (MAS), streptococcosis, dan mycobacteriosis pada budidaya ikan air tawar. Vaksin trivalen yang dicobakan merupakan campuran dari tiga jenis antigen, yaitu Aeromonas hydrophila-AHL0905-2 (Ah), Streptococcus agalactiae N14G (Sa), dan Mycobacterium fortuitum 31 (Mf) dengan formulasi $2 \mathrm{Ah} \mathrm{:} 2 \mathrm{Sa}: 1 \mathrm{Mf}(\mathrm{v} / \mathrm{V})$. Ikan uji yang digunakan adalah ikan lele, nila, dan gurami; masing-masing jenis ikan tersebut merupakan representasi ikan yang rentan terhadap penyakit MAS, streptococcosis, dan mycobacteriosis. Perlakuan yang diterapkan adalah metode aplikasi dengan menggunakan vaksin trivalen melalui: (A) perendaman, (B) pakan, (C) perendaman + booster, (D) pakan + booster, dan (E) tanpa pemberian vaksin sebagai kontrol. Efektivitas metode aplikasi vaksin tersebut dievaluasi melalui nilai titer antibodi spesifik dan relative percentage survival (RPS) pasca uji tantang terhadap patogen target. Hasil penelitian menunjukkan bahwa RPS dari metode aplikasi vaksin trivalen pada ketiga jenis ikan uji yang mencapai nilai $\geq 50 \%$ secara keseluruhan hanya diperoleh pada aplikasi melalui rendam + booster. Oleh karena itu, metode aplikasi tersebut dapat direkomendasikan untuk digunakan pada pembudidaya ikan air tawar.
\end{abstract}

KATA KUNCl: aplikasi; vaksin trivalen; penyakit bakterial; ikan air tawar

ABSTRACT: The effecetiveness of trivalen vaccineapplication methods to prevent potential bacterial diseases in freshwater aquaculture. By: Taukhid, Tuti Sumiati, and Septyan Andriyanto

This study aims to obtain a method of application of trivalent vaccine that gives the best level of protection for prevention of potential bacterial diseases such as motileAeromonas septicemia (M AS), streptococcosis, and ycobacteriosis in freshwater fish culture. The trivalent vaccine is a mixture of threetypes of antigens, namely Aeromonas hydrophilaAHL0905-2 (Ah), Streptococcus agalactiae N14G (Sa), and Mycobacterium fortuitum 31 (M f) with the formulation of $2 \mathrm{Ah}: 2 \mathrm{Sa}: 1 \mathrm{Mf}(\mathrm{v} / \mathrm{v})$. The test fish used were catfish, tilapia, and giant gourami; each fish is a representation of fish vulnerable to M AS, streptococcosis, and mycobacteriosis. The applied treatments werethe application methods of trivalent vaccine through (A) immersion, (B) feed, (C) immersion + booster, (D) feed + booster, and (E) without vaccine as the control. The effectiveness of vaccine application methods was evaluated through the value of specific antibody titer and relative percentage survival (RPS) post-challenge test against thetarget pathogens. The results showed that overall, the RPS value of $>50 \%$ on all threetest fish species was obtained only by the vaccine application through soak + booster. Therefore, the application method can be recommended to be used in freshwater fish culture.

KEYWORDS: application; trivalen vaccine; bacterial diseases; freshwater aquaculture

\section{PENDAHULUAN}

Penyakit ikan merupakan salah satu kendala dalam pengembangan perikanan budidaya. Pengendalian penyakit ikan, selama ini lebih mengandalkan pada

\footnotetext{
\# Korespondensi: Balai Riset Perikanan Budidaya Air Tawar dan Penyuluhan Perikanan. JI. Sempur No. 1, Bogor 16154, Indonesia.

Tel. + 622518313200

E-mail: taukhid_as@yahoo.co.id
}

penggunaan bahan kimia/obat/antibiotik. Penggunaan bahan-bahan tersebut memiliki dampak negatif; baik terhadap lingkungan perairan, ikan, maupun konsumen. Oleh karena itu, upaya pencegahan dan pengendalian yang lebih ramah lingkungan, aman terhadap ikan dan konsumen harus menjadi paradigma baru dalam rangka peningkatan produksi perikanan budidaya yang berkelanjutan (Taukhid et al., 2012a).

Vaksinasi pada perikanan budidaya merupakan salah satu upaya pencegahan terhadap infeksi patogen yang 
efektif, dan menjamin peningkatan produksi akuakultur yang berkelanjutan (Gudding $\&$ Goodrich, 2014, Taukhid et al., 2014b; Li et al., 2015, Park et al., 2016).

Pencegahan penyakit motile aeromonas septicemia (MAS) pada ikan lele dengan aplikasi vaksin "HydroVac" mampu menekan tingkat kematian sebesar 30\%40\% dan vaksin "StreptoVac" akibat penyakit streptococcosis pada ikan nila sebesar 20\%30\%(Taukhid et al., 2015). Selanjutnya dilaporkan juga bahwa pencegahan penyakit mycobacteriosis pada ikan gurami melalui vaksinasi dengan menggunakan antigen Mycobacterium fortuitum, diperoleh hasil $20 \%$ lebih tinggi dibandingkan tanpa pemberian vaksin (Taukhid et al., 2014a). Salah satu keunggulan yang dimiliki oleh vaksinvaksin tersebut adalah kemampuannya untuk bereaksi silang terhadap varian bakteri heterolog yang terdapat di sentra budidaya ikan air tawar (Taukhid et al., 2011, Taukhid et al., 2012b, Taukhid et al., 2014d).

Keterbatasan vaksin monovalen (single antigen) adalah fakta bahwa di lingkungan budidaya ditemukan penyakit bakterial yang beragam, sehingga pembudidaya harus memberikan lebih dari satu jenis vaksin untuk mencegah penyakit-penyakit tersebut (Taukhid et al., 2014c). Pada kondisi tersebut, penggunaan vaksin monovalen tidak dapat menjamin perlindungan terhadap keberagaman penyakit yang sejatinya sudah endemik pada suatu kawasan budidaya (Huang et al., 2012); dan vaksinasi yang dilakukan lebih dari satu/dua kali menjadi mahal dan tidak praktis. Hasil kajian pascarilis terhadap vaksin Hydrovac dan Streptovac menyimpulkan perlunya sediaan vaksin dengan manfaat tidak hanya terhadap satu jenis penyakit, tapi secara sinergis mampu mencegah beberapa jenis penyakit yang sering menjadi kendala pada budidaya ikan (Taukhid et al., 2014c).

Penelitian sebelumnya telah diketahui bahwa vaksin trivalen mampu bekerja sinergis dan memiliki efikasi, serta berpotensi sebagai sediaan vaksin yang dapat digunakan untuk mencegah tiga jenis penyakit (MAS, streptococcosis, dan mycobacteriosis) pada budidaya ikan air tawar (Taukhid et al., 2016). Berdasarkan hasil tersebut, maka perlu diketahui metode aplikasi vaksin tersebut yang secara teknisekonomis memberikan efikasi terbaik disesuaikan dengan stadia/ukuran, serta segmentasi usaha budidaya ikan yang ada di masyarakat.

Penelitian ini bertujuan untuk mendapatkan teknik aplikasi vaksin trivalen yang memberikan level proteksi terbaik untuk pencegahan penyakit potensial, motile aeromonas septicemia (MAS), streptococcosis, dan mycobacteriosis pada budidaya ikan air tawar.

\section{BAHAN DAN METODE}

\section{Ikan dan Wadah Uji}

Pada penelitian ini, penentuan jenis ikan uji didasarkan pada informasi epizootiologi dari masingmasing jenis penyakit. Penyakit MAS paling sering ditemukan pada budidaya ikan lele, sedangkan penyakit streptococcosis dan mycobacteriosis masing-masing menginfeksi pada budidaya ikan nila, dan ikan gurami (Maskur et al., 2014). Berdasarkan informasi tersebut, maka ketiga jenis ikan tersebut digunakan sebagai representasi jenis-jenis ikan rentan terhadap ketiga jenis penyakit tersebut. Ikan lele dan nila diperoleh dari Pusat Produksi, Inspeksi dan Sertifikasi Hasil Perikanan (PPISHP), Ciganjur, Jakarta; sedangkan ikan gurami didatangkan dari penangkar/Unit Perbenihan Rakyat (UPR) dari wilayah Citayam, Bogor.

Status "specific pathogen free (SPF)" terhadap patogen target didasarkan pada hasil diagnosis bakteriologis terhadap sampel sebelum digunakan. Ukuran bobot masing-masing jenis ikan uji merupakan kisaran rentan terhadap infeksi patogen target (ikan lele 8,31 \pm 3,30 g/ekor; nila 10,69 \pm 4,08 g/ekor; dan gurami 3,93 $\pm 0,77$ g/ekor). Jumlah ikan uji untuk masing-masing jenis sebanyak 1.500 ekor. Sebanyak 1.000 ekor digunakan sebagai ikan uji utama, sedangkan sisanya digunakan sebagai ikan model dalam proses penyiapan bakteri uji (Koch's postulate), serta penentuan nilai dosis letal $50 \%\left(\mathrm{LD}_{50}\right)$ untuk masing-masing jenis bakteri target sebelum pelaksanaan uji tantang.

Proses karantina dan adaptasi ikan uji dilakukan dalam wadah yang berbeda dan berlangsung selama tiga minggu. Ikan lele dan gurami dipelihara dalam empat buah bak fiber glass volume 2.000 liter, sedangkan ikan nila dipelihara dalam tiga buah bak beton berukuran $2 \mathrm{~m} \times 4 \mathrm{~m} \times 1 \mathrm{~m}$. Setiap bak fiber dan bak beton dilengkapi dengan aerasi secukupnya. Pemeliharaan ikan pasca-vaksinasi dilakukan dalam 15 buah bak fiber glass volume 200 liter. Uji tantang dilakukan dalam akuarium/bak plastik volume 80 liter sebanyak 72 buah.

Sumber air untuk seluruh tahapan penelitian berasal dari air tanah. Pakan diberikan secara adlibitum sebanyak dua kali/hari (pagi dan sore) dengan jumlah $3 \% 5 \%$ hari dari biomass ikan. Jenis pakan yang digunakan adalah pakan komersial dengan kadar protein kasar sebesar $28 \%$

\section{Sediaan Vaksin dan Perlakuan}

Vaksin monovalen (single antigen) yang digunakan adalah: (1) vaksin Hydrovac yang mengandung antigen 
bakteri Aeromonas hydrophila-AHL0905-2; (2) vaksin Streptovac yang mengandung antigen bakteri Streptococcus agalactiae N14G; dan (3) vaksin untuk pencegahan mycobacteriosis yang mengandung antigen bakteri M ycobacterium fortuitum 31 (Taukhid et al., 2016). Preparasi sediaan baku vaksin-vaksin monovalen tersebut mengacu pada standar produksi yang telah dipatenkan (Taukhid et al., 2011; 2012b; 2014d). Pembuatan vaksin trivalen dilakukan dengan mencampur ketiga sediaan baku vaksin, menjadi satu sediaan dengan perbandingan untuk antigen bakteri A. hydrophila : S. agalactiae: M. fortuitum adalah 2:2:1 (v/v). Penentuan formulasi tersebut didasarkan pada hasil konversi sediaan baku vaksin dalam bobot kering beku (freeze dry), sehingga diperoleh sediaan vaksin trivalen yang mengandung antigen dari masing-masing jenis antigen bakteri penyusunnya sebanyak $10^{11} \mathrm{cfu} /$ $\mathrm{mL}$.

Perlakuan yang diterapkan adalah metode aplikasi vaksin trivalen dengan lima kelompok perlakuan, yaitu: A) melalui perendaman (aplikasi tunggal), B) melalui pakan (aplikasi tunggal), C) melalui perendaman dengan booster, D) melalui pakan dengan booster, dan E) tanpa pemberian vaksin (kontrol).

Vaksinasi melalui perendaman dilakukan dengan cara merendam ikan uji dalam larutan vaksin $(1 \mathrm{~mL}$ sediaan vaksin dilarutan dalam 10 liter air), selama 30 menit. Vaksinasi melalui pakan dilakukan dengan cara mencampur pakan (pellet) dengan vaksin pada dosis 2 $\mathrm{mL} / \mathrm{kg}$ bobot biomassa ikan, dan diberikan selama tujuh hari. Vaksinasi ulang (booster) dilakukan setelah tiga minggu dari akhir pemberian vaksinasi pertama (priming), dengan teknik dan periode pemberian yang sama dengan vaksinasi pertama.

Vaksinasi/periode vaksinasi disesuaikan dengan design perlakuan, sehingga pelaksanaan uji tantang dapat dilakukan secara serentak. Secara skematik, jadwal pemberian vaksin hingga proses uji tantang dapat dilihat pada Tabel 1.

\section{Uji Tantang}

Uji tantang dilakukan pada minggu ke 3-4 dari saat vaksinasi terakhir dengan cara infeksi buatan terhadap patogen target pada dosis letal $50 \%\left(L_{50}\right)$. Penentuan nilai dosis letal $50 \%$ untuk masing-masing jenis patogen dan ikan uji didasarkan pada hasil pengujian yang dilakukan secara paralel terhadap populasi ikan yang sama. Pelaksanaan uji tantang selengkapnya disarikan dalam Tabel 2.

\section{Pengamatan dan Analisis Data}

Pengamatan terhadap tingkah laku, gejala klinis, dan mortalitas ikan uji dilakukan setiap hari sejak masa karantina hingga akhir periode penelitian. Selama periode uji tantang, dilakukan pengambilan sampel secara selektif terhadap individu ikan yang menunjukkan tingkah laku dan/atau gejala klinis spesifik, minimum satu ekor dari masing-masing kelompok perlakuan untuk diagnosis/identifikasi patogen target.

Pengukuran titer antibodi dilakukan secara pooling untuk tiap kelompok perlakuan. Pada penelitian ini, pengukuran titer antibodi untuk ikan lele dan nila masing-masing ditentukan terhadap bakteri Aeromonas hydrophila-AHL0905-2, dan Streptococcus agalactiae N14G, sedangkan pada ikan gurami terhadap dua jenis bakteri, yaitu A. hydrophila-AHL0905-2 dan Mycobacterium fortuitum 31. Efektivitas metode aplikasi vaksin trivalen dievaluasi berdasarkan dua pendekatan, yaitu (1) nilai titer antibodi dan (2) level proteksi relatif atau RPS.

Pengukuran titer antibodi dilakukan menurut meto de yang dikembangkan oleh Roberson (1990) dan Katz (2011) yaitu teknik aglutinasi langsung dengan menggunakan microtitre plate. Titer antibodi ikan uji pada awal diukur sesaat sebelum proses vaksinasi, dan selanjutnya diukur dengan interval waktu satu minggu hingga akhir penelitian.

Efikasi vaksin diukur dengan besaran nilai "relative percentage of survival" (RPS). RPS dihitung menurut formula yang dikembangkan oleh Amend (1981), yaitu RPS $=(1-\{\%$ mortalitas ikan yang divaksin $/ \%$ mortalitas ikan kontrol\}) x 100.

\section{HASIL DAN BAHASAN}

Hasil pemeriksaan secara bakteriologis yang dilakukan terhadap populasi ikan uji sebelum digunakan, pada populasi ikan lele, nila, dan gurami masing-masing tidak terdapat adanya infeksi bakteri A. hydrophila, S. agalactiae, dan M. fortuitum. Berdasarkan hasil pemeriksaan yang dilakukan secara acak dan berkala selama periode karantina, dapat diasumsikan bahwa seluruh populasi ikan uji pada penelitian ini adalah specific pathogen free(SPF) terhadap bakteri target.

Perubahan tingkah laku dan gejala klinis ikan uji selama proses uji tantang terhadap bakteri target, secara umum dapat disarikan sebagai berikut: pada ikan lele, abnormalitas mulai terlihat delapan jam pascainfeksi buatan dengan bakteri A. hydrophila. Gejala yang tampak dimulai dengan warna tubuh kusam/ gelap, nafsu makan menurun, dan ekses lendir. Selanjutnya terlihat perdarahan pada tubuh ikan baik pada pangkal sirip, sekitar anus, dan bagian tubuh lainnya. Pada 24 jam pascainfeksi, terlihat adanya luka yang berkembang menjadi borok (Gambar 1a), perut 
Tabel 1. Skema jadwal pemberian vaksin trivalen dan uji tantang pada ikan uji (lele, nila, dan gurami)

Table 1. Time table of vaccination and challenge test on African catfish, nile tilapia fish, and giant gourami fish

\begin{tabular}{|c|c|c|c|c|c|c|c|c|c|c|}
\hline \multirow{2}{*}{$\begin{array}{l}\text { Perlakuan } \\
\text { Treatments }\end{array}$} & \multicolumn{10}{|c|}{ Minggu (Weeks) } \\
\hline & 1 & 2 & 3 & 4 & 5 & 6 & 7 & 8 & 9 & $\begin{array}{lll}10 & 11 & \ldots\end{array}$ \\
\hline $\begin{array}{l}\text { Rendam } \\
\text { Immersion }\end{array}$ & & & & & & & & & & $\begin{array}{l}\text { Uji tantang } \\
\text { Challenge test }\end{array}$ \\
\hline $\begin{array}{l}\text { Pakan } \\
\text { Oral }\end{array}$ & & & & & & & & & & $\begin{array}{l}\text { Uji tantang } \\
\text { Challenge test }\end{array}$ \\
\hline $\begin{array}{l}\text { Rendam + booster } \\
\text { Immersion + booster }\end{array}$ & & & & & & & & & & $\begin{array}{l}\text { Uji tantang } \\
\text { Challenge test }\end{array}$ \\
\hline $\begin{array}{l}\text { Pakan + booster } \\
\text { Oral + booster }\end{array}$ & & & & & & & & & & $\begin{array}{l}\text { Uji tantang } \\
\text { Challenge test }\end{array}$ \\
\hline $\begin{array}{l}\text { Kontrol } \\
\text { Control }\end{array}$ & & & & & & & & & & $\begin{array}{l}\text { Uji tantang } \\
\text { Challenge test }\end{array}$ \\
\hline
\end{tabular}

Keterangan: - adalah waktu/periode pemberian vaksin trivalent

Note: - is a time/period of trivalen vaccine application

lembek dan bengkak (dropsy) yang berisi cairan merah kekuningan.

Pada ikan nila yang diinfeksi dengan bakteri S. agalactiae, abnormalitas mulai tampak 48 jam pasca infeksi. Gejala yang terlihat adalah warna tubuh gelap (Gambar 1b), lemah, exopthalmia, pendarahan, perut gembung dan/atau luka yang berkembang menjadi borok. Pada ikan gurame yang diinfeksi dengan bakteri A. hydrophila, menunjukkan gejala klinis seperti halnya yang terjadi pada ikan lele dan mulai terlihat 24 jam pascainfeksi buatan. Gejala klinis yang tampak antara lain warna tubuh kusam/gelap, nafsu makan menurun, dan ekses lendir. Bercak merah di sekitar lokasi penyuntikan, selanjutnya berkembang menjadi luka yang serius (Gambar 1c). Sedangkan pada ikan gurame yang diinfeksi dengan bakteri $M$. fortuitum, abnormalitas mulai tampak empat hari pascainfeksi. Gejalaklinis awal antara lain hilang nasfu makan, lemah, bercak merah pada lokasi penyuntikan, selanjutnya berkembang menjadi luka yang khas berwarna

Tabel 2. Uji tantang pada ikan lele, nila, dan gurami terhadap patogen target, dosis infeksi, dan lama waktu pengamatan

Table 2. Challenge test against targeted pathogen, infection dose, and terminated time of observation on catfish, tilapia fish, and giant gouramy fish

\begin{tabular}{|c|c|c|c|c|}
\hline $\begin{array}{l}\text { Jenis ikan } \\
\text { Species }\end{array}$ & $\begin{array}{l}\text { Patogen } \\
\text { Pathogen }\end{array}$ & $\begin{array}{l}\text { Dosis letal } 50 \%\left(L_{50}\right) \\
\text { Lethal dose } 50 \%\left(L_{50}\right)\end{array}$ & $\begin{array}{l}\text { Infeksi buatan } \\
\text { Artificial infection }\end{array}$ & $\begin{array}{l}\text { Periode pengamatan (hari) } \\
\text { Observation period (day) }\end{array}$ \\
\hline $\begin{array}{l}\text { Lele } \\
\text { African catfish }\end{array}$ & $\begin{array}{l}\text { Aeromonas } \\
\text { hydrophila }\end{array}$ & $10^{6} \mathrm{cfu} / \mathrm{mL}$ & $\begin{array}{l}\text { Intramuskular } \\
\text { Intramuscular }\end{array}$ & 10 \\
\hline $\begin{array}{l}\text { Gurami } \\
\text { Giant gourami }\end{array}$ & $\begin{array}{l}\text { Aeromonas } \\
\text { hydrophila }\end{array}$ & $10^{3} \mathrm{cfu} / \mathrm{mL}$ & Intraperitoneal & 10 \\
\hline $\begin{array}{l}\text { Nila } \\
\text { Tilapia }\end{array}$ & $\begin{array}{l}\text { Streptococcus } \\
\text { agalactiae }\end{array}$ & $10^{6} \mathrm{cfu} / \mathrm{mL}$ & $\begin{array}{l}\text { Intramuskular } \\
\text { Intramuscular }\end{array}$ & 30 \\
\hline $\begin{array}{l}\text { Gurami } \\
\text { Giant gouramy }\end{array}$ & $\begin{array}{l}\text { Mycobacterium } \\
\text { fortuitum }\end{array}$ & $10^{7} \mathrm{cfu} / \mathrm{mL}$ & $\begin{array}{l}\text { Intramuskular } \\
\text { Intramuscular }\end{array}$ & 45 \\
\hline
\end{tabular}


transparan (Gambar 1d). Pada kondisi tersebut, secara internal telah mengalami pembengkakan pada organ limpa, ginjal, dan hati.

Titer antibodi merupakan salah satu parameter yang umum digunakan sebagai indikator adanya pembentukan respons kekebalan spesifik setelah pemberian vaksin. Nilai titer antibodi dari masingmasing jenis ikan uji dan kelompok perlakuan (Gambar 2a, b, c, dan d).

Pada Gambar 2 tersebut menunjukkan bahwa nilai titer antibodi tertinggi hingga pengenceran ke-512 pada ikan lele terjadi pada minggu ke-7 dan 8 (Gambar 2a). Pada ikan nila, nilai titer antibodi tertinggi hingga pengenceran ke-256 terjadi pada minggu ke-8 (Gambar 2b). Pada ikan gurami, nilai titer antibodi tertinggi hingga pengenceran ke-256 terjadi pada minggu ke-6 hingga 10 (Gambar 2c, d).

Taukhid et al. (2014b) menyatakan bahwa tingginya nilai titer antibodi tidak sepenuhnya menggambarkan level proteksi mutlak terhadap patogen target, namun secara umum dapat dikatakan bahwa semakin tinggi nilai titer antibodi mengindikasikan adanya pembentukan respons tanggap kebal yang berkorelasi positif terhadap kemampuan menangkal infeksi patogen target. Berdasarkan hasil pengukuran nilai titer antibodi, secara keseluruhan dapat dikatakan bahwa nilai tertinggi diperoleh pada aplikasi vaksin trivalen melalui perendaman dan/atau pakan (oral), dilanjutkan dengan vaksinasi ulang (booster) yang diberikan sesuai dengan metode aplikasi yang diterapkan pada saat vaksinasi pertama (priming).

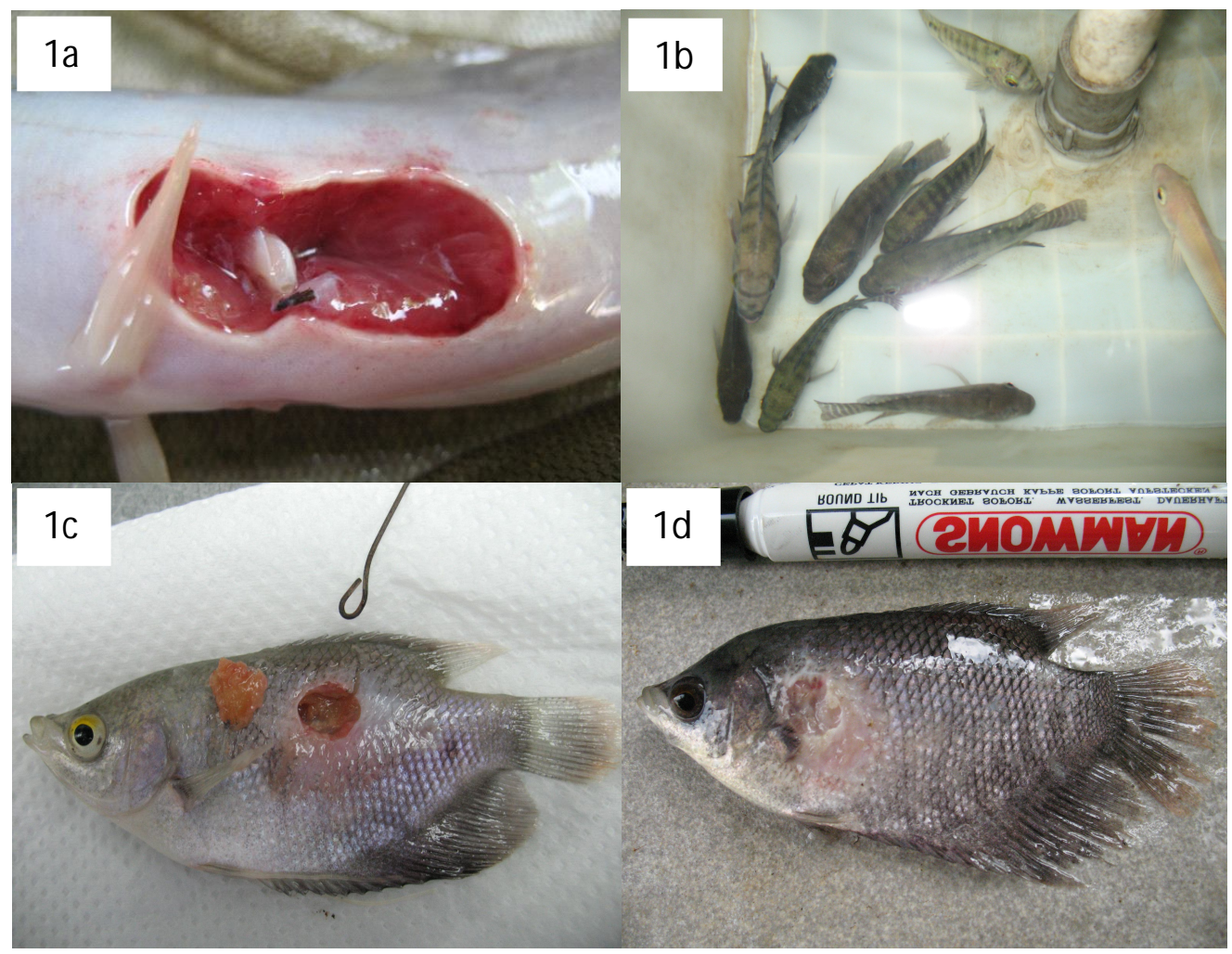

Gambar 1. Gejala klinis ikan uji selama proses uji tantang: ikan lele terhadap bakteri Aeromonas hydrophila, mengalami luka/borok yang serius (a); ikan nila terhadap bakteri Streptococcus agalactiae, perubahan warna tubuh menjadi lebih gelap (b); ikan gurame terhadap bakteri Aeromonas hydrophila, mengalami luka/borok yang serius (c); dan ikan gurame terhadap bakteri Mycobacterium fortuitum, mengalami luka/borok dengan warna pucat (d).

Figure 1. Clinical symptoms of fish during challenge test: the catfish challenged agaisnt

Aeromonas hydrophila, suffered serious wounds/ulcers (a); the tilapia were challenged against Streptococcus agalactiae, some of tilapia have undergone changes in body color darkened (b); the giant gouramy were challenged against Aeromonas hydrophila, suffered a serious wounds/ulcers (c); and the giant gouramy were challenged against Mycobacterium fortuitum, suffered transparant deepsores (d). 

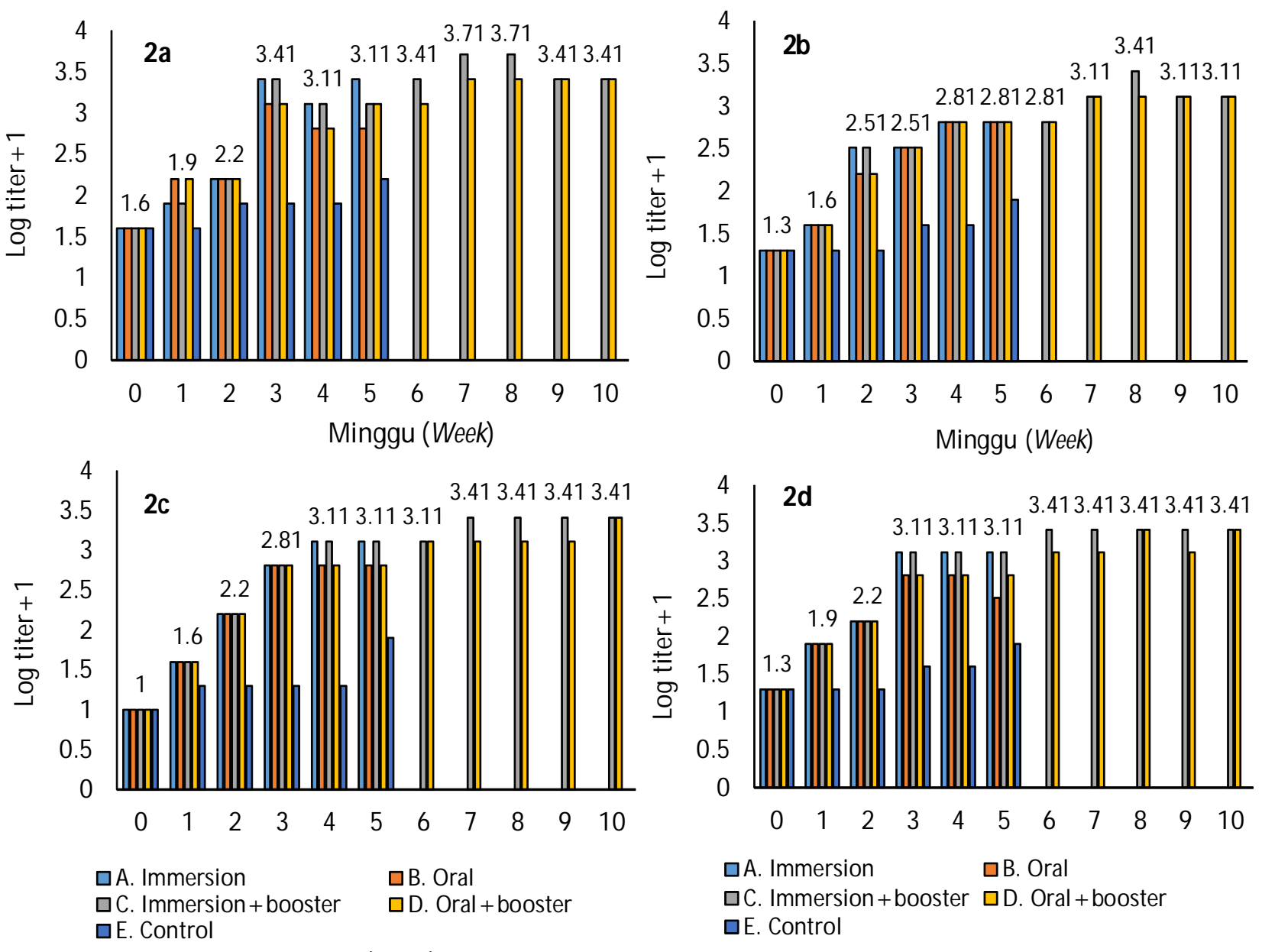

$$
\text { Minggu (W eek) }
$$

Minggu (Week)

Gambar 2. Nilai titer antibodi serum darah ikan lele yang diamati setiap minggu terhadap bakteri Aeromonas hydophila-AHL0905-2 (a); ikan nila terhadap bakteri Streptococcus agalactiae N14G (b); ikan gurami terhadap bakteri Aeromonas hydophila-AHL0905-2 (c); dan terhadap bakteri M ycobacterium fortuitum 31 (d).

Figure 2. The antibody titre value of African catfish serum analysed weekly against Aeromonas hydophila-AHL09052 (a); tilapia serum against Streptococcus agalactiae N14G (b); giant goramy against Aeromonas hydophila-AHL0905-2 (c); and against Mycobacterium fortuitum 31 (d).

Rataan persentase mortalitas kumulatif selama proses uji tantang pada ikan lele terhadap bakteri A. hydrophila, menunjukkan bahwa ikan yang divaksin memberikan tingkat mortalitas yang lebih rendah dibandingkan dengan kelompok kontrol; sedangkan pada kontrol negatif tidak ada ikan uji yang mati (Gambar 3a). Kematian ikan mulai terjadi sejak hari pertama pasca infeksi buatan, dan berlangsung sporadik hingga hari keempat. Setelah melewati periode per akut yang berlangsung hingga hari keempat, ikan lele mengalami proses penyembuhan dan bertahan hidup hingga akhir periode pengamatan.

Hasil analisis menunjukkan bahwa persentase rataan mortalitas pada aplikasi vaksin trivalen melalui perendaman $(A)$ berbeda nyata dengan kelompok perlakuan lainnya $(P<0,05)$; kecuali dengan kelompok perlakuan aplikasi melalui pakan (B). Sedangkan pemberian vaksin trivalen melalui perendaman + booster $(\mathrm{C})$ berbeda nyata dengan kelompok perlakuan lainnya $(P<0,05)$; kecuali dengan kelompok perlakuan aplikasi melalui pakan + booster (D).

Taukhid et al. (2015) mendapatkan nilai rataan mortalitas ikan lele pada pengujian vaksin Hydrovac (monovalen A. hydrophila) di akhir periode uji tantang terhadap bakteri A. hydrophila sebesar 7,15\% dan pada kelompok kontrol sebesar $49,15 \%$ Hasil yang diperoleh pada penelitian ini memperlihatkan performa yang hampir sama, dan hasil uji statistik menunjukkan perbedaan nyata $(P<0,05)$ terhadap kontrol. 
Pola kematian pada ikan nila yang diuji tantang dengan bakteri Streptococcus agalactiae N14G ditunjukkan pada Gambar 3b. Ikan yang divaksin memberikan tingkat mortalitas yang lebih rendah dibandingkan dengan kontrol, dan pada kontrol negatif tidak ditemukan adanya kematian. Kematian yang terjadi pada ikan nila selama perio de uji tantang, lebih mengarah pada pola kematian yang bersifat akut hingga per kronik; kematian mulai terjadi sejak hari pertama, dan berlangsung hingga tiga minggu setelahnya. Setelah melewati masa inkubasi jenis bakteri yang diinfeksikan (1-3 minggu), ikan nila mengalami proses
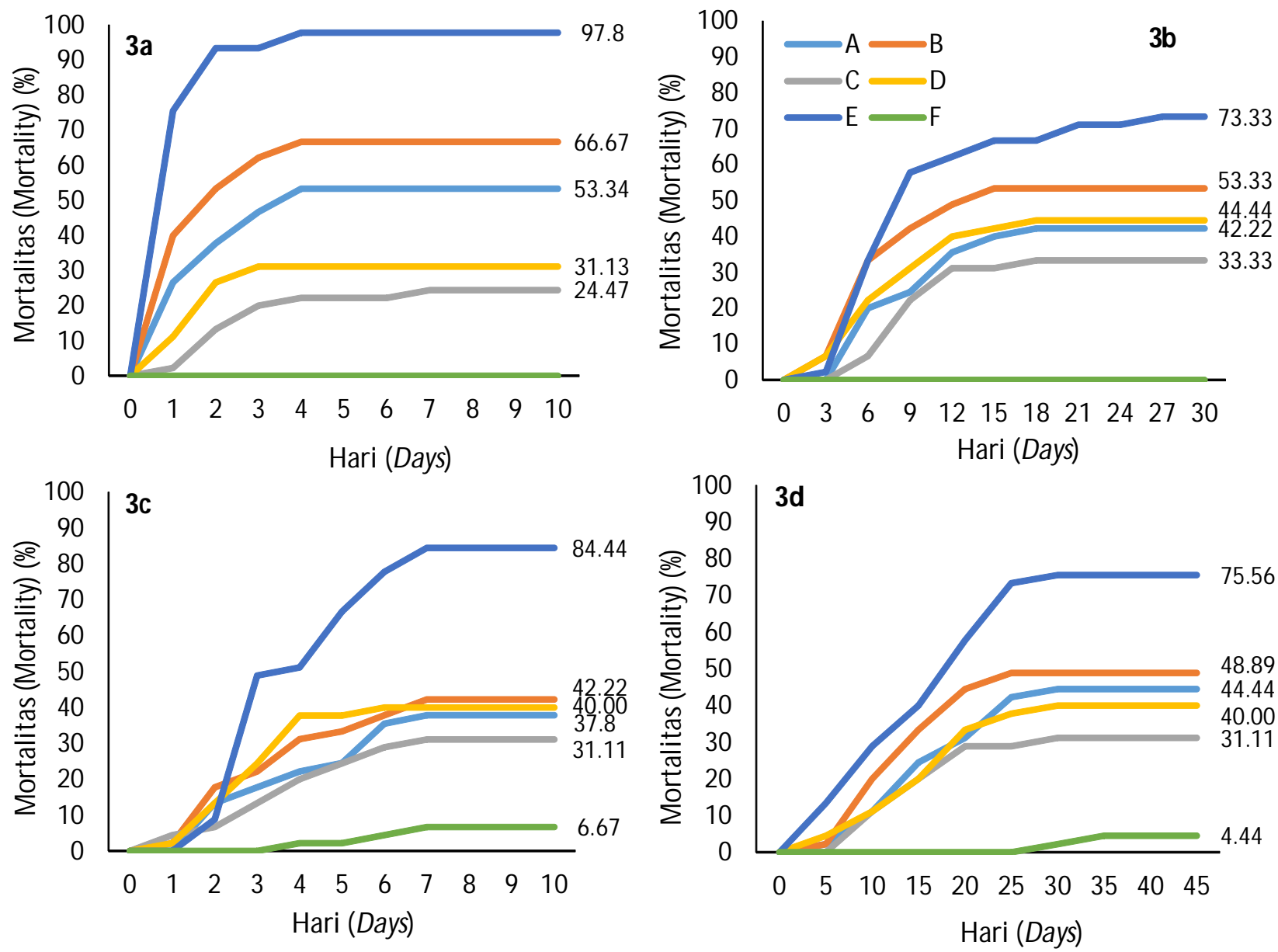

Gambar 3. Mortalitas kumulatif ikan lele (3a) yang diberi vaksin trivalen dengan metode pemberian berbeda selama uji tantang terhadap bakteri Aeromonas hydrophila-AHL0905-2 pada dosis letal $50 \%\left(\mathrm{LD}_{50}\right)$ yang berlangsung selama 10 hari; ikan nila ( $3 \mathrm{~b}$ ) yang diuji tantang bakteri Streptococcus agalactiae N14G pada dosis letal $50 \%\left(\mathrm{LD}_{50}\right) \approx 10^{6} \mathrm{cfu} / \mathrm{mL}$ per ekor ikan yang berlangsung selama 30 hari; ikan gurame (3c) yang diuji tantang terhadap bakteri Aeromonas hydrophila-AHL0905-2 pada dosis letal $50 \%\left(\mathrm{LD}_{50}\right)$ yang berlangsung selama 10 hari; dan ikan gurami $(3 \mathrm{~d})$ yang diuji tantang bakteri Mycobacterium fortuitum 31 pada dosis letal $50 \%\left(\mathrm{LD}_{50}\right) \approx 10^{7} \mathrm{cfu} / \mathrm{mL}$ per ekor ikan yang berlangsung selama 45 hari. $A=$ vaksinasi melalui rendam, $B=$ vaksinasi melalui pakan, $C=$ vaksinasi melalui rendam + booster melalui rendam, $\mathrm{D}=$ vaksinasi melalui pakan + booster melalui pakan, $\mathrm{E}=$ kontrol positif, dan $\mathrm{F}=$ kontrol negatif.

Figure 3. Cummulative mortality of African catfish (a) vaccinated through different applications of trivalen vaccine during challenge test against Aeromonas hydrophila-AHL0905-2 at the lethal dose of 50\% $\left(\mathrm{LD}_{50}\right)$ for ten days observation; and nile tilapia (b) were challenged against Streptococcus agalactiae N14G at the lethal dose of $50 \%\left(\mathrm{LD}_{50}\right) \approx 10^{6} \mathrm{cfu} / \mathrm{mL}$ per fish for 30 days observation; giant goramy (c) were challenged against Aeromonas hydrophila-AHL0905-2 at the lethal dose of 50\% $\left(\mathrm{LD}_{50}\right)$ for ten days observation; and giant goramy (d) were challenged against Mycobacterium fortuitum 31 at the lethal dose of $50 \%\left(L_{50}\right) \approx$ $10^{7} \mathrm{cfu} / \mathrm{mL}$ per fish for 45 days observation. $A=$ vaccination by immersion, $B=$ vaccination by oral, $C=$ vaccination by immersion + booster immersion, $D=$ vaccination by oral + booster oral, $E=$ positive control (no vaccine, challenged), and $\mathrm{F}=$ negative control (no vaccine, no challenge). 
penyembuhan dan mampu bertahan hidup (Gambar 3b). Hasil tersebut menunjukkan adanya kecenderungan bahwa aplikasi vaksin trivalen pada ikan nila melalui perendaman + booster, memberikan nilai efikasi yang lebih baik dibandingkan dengan ketiga meto de aplikasi lainnya.

Pada ikan gurami, hasil akhir dari proses uji tantang terhadap bakteri A. hydrophila, menunjukkan bahwa ikan yang divaksin memberikan tingkat mortalitas yang lebih rendah dibandingkan dengan kontrol (Gambar 3c). Namun, pada kontrol negatif terjadi kematian ikan sebesar $6,67 \%$ Hal ini diduga akibat adanya kontaminasi silang selama proses uji tantang, karena pengujian dilakukan dalam ruangan yang sama dengan sistem biosekuriti yang relatif sulit dikendalikan.

Kematian ikan gurami yang diuji tantang dengan bakteri $A$. hydrophila memperlihatkan pola yang berbeda dengan ikan lele. Kematian mulai terjadi sejak hari pertama, selanjutnya pola kematian akut mulai terjadi pada hari kedua hingga hari ketujuh. Setelah melewati periode akut yang berlangsung hingga hari ketujuh, umumnya ikan gurami mengalami proses penyembuhan dan sebagian besar mampu bertahan hidup (Gambar 3c).

Pengujian vaksin Hydrovac (monovalen $A$. hydrophila) untuk mencegah "penyakit merah" pada ikan gurami melalui perendaman, diperoleh nilai mortalitas sebesar 23,05\% dan pada kontrol sebesar 48,30\%(Taukhid et al., 2015). Hasil yang diperoleh pada penelitian ini memperlihatkan performa yang hampir sama, dan berbeda nyata $(P<0,05)$.

Pola kematian yang terjadi pada ikan gurami yang diuji tantang dengan bakteri M. fortuitum 31 disajikan pada Gambar 3d. Ikan yang divaksin memberikan tingkat mortalitas yang lebih rendah dibandingkan dengan kontrol, dan pada kontrol negatif ditemukan adanya kematian sebesar 4,44\% Kematian yang terjadi pada ikan gurami selama periode uji tantang, lebih mengarah pada pola kematian yang bersifat sub-akut hingga kronik; di mana kematian mulai terjadi pada lima hari pertama sejak infeksi buatan, dan berlangsung hingga hari ke-35 (minggu ke-5). Setelah melewati masa inkubasi dari jenis bakteri patogen yang diinfeksikan (1-5 minggu), ikan gurami mengalami proses penyembuhan dan mampu bertahan hidup hingga akhir periode pengamatan (Gambar 3d).

Taukhid et al. (2014a) mendapatkan nilai mortalitas populasi ikan gurami yang divaksin dengan vaksin monovalen M. fortutium 31 (MycofortyVac) sebesar $16,67 \% 26,67 \%$ dibandingkan dengan tanpa pemberian vaksin sebesar 33,33\%39,33\% Bangkit (2011) menyatakan bahwa vaksin M. fortuitum dalam bentuk sediaan broth dengan dosis $10^{7} \mathrm{cfu} / \mathrm{mL}$ dan/atau bentuk sediaan extra cellular product (ECP) pada dosis $10^{\circ} \mathrm{cfu} /$ $\mathrm{mL}$ yang diberikan melalui perendaman untuk mencegah mycobacteriosis pada ikan gurami, mampu menginduksi kekebalan spesifik terhadap mycobacteriosis dengan nilai sintasan $80 \%$ dan tingkat gejala klinis ringan setelah diuji tantang terhadap bakteri M. fortuitum homolog.

Relative percentage of survival (RPS) merupakan nilai proporsi mortalitas antara kelompok ikan yang divaksin dengan kontrol selama periode uji tantang (challenge) atau wabah penyakit (disease outbreak). Nilai RPS merupakan salah satu parameter utama yang digunakan dalam mengevaluasi suatu sediaan vaksin ikan. Pada Tabel 3 disajikan nilai RPS yang dicapai oleh vaksin trivalen yang diaplikasikan dengan metode yang berbeda.

Pada Tabel 3 terlihat bahwa RPS dari metode aplikasi vaksin trivalen pada ketiga jenis ikan uji (lele, nila, dan gurami) yang mencapai nilai $\geq 50 \%$ umumnya didominasi oleh metode aplikasi rendam + booster. Pada ikan lele yang diuji tantang dengan bakteri $\mathrm{A}$. hydrophila, nilai RPS sebesar lebih dari $50 \%$ hanya didapatkan pada vaksinasi melalui rendam + booster (C) dan pakan + booster (D) masing-masing sebesar $75,00 \%$ dan $68,20 \%$ Pada ikan gurami yang diuji tantang dengan jenis bakteri yang sama (A. hydrophila), menunjukkan bahwa semua metode vaksinasi memperoleh nilai RPSyang mencapai $\geq 50 \%$ Pada ikan nila dan ikan gurami yang diuji tantang masing-masing dengan bakteri S. agalactiae dan $M$. fortuitum menunjukkan nilai RPS sebesar $56,50 \%$ dan $58,80 \%$ hanya didapatkan pada vaksinasi melalui metode rendam + booster.

Capaian nilai RPS yang relatif rendah $(<50 \%$ juga diperoleh dari hasil penelitian sebelumnya yang dilakukan oleh Taukhid et al. (2016), yaitu dari seluruh pengujian terhadap jenis ikan yang sama (lele, nila, dan gurami) dengan aplikasi tunggal melalui metode perendaman hanya dicapai kisaran nilai RPS antara 7,14\% 45,00\% Berdasarkan nilai capaian RPS yang didapat pada penelitian ini, maka sediaan vaksin trivalen lebih sesuai diaplikasikan melalui metode perendaman + booster agar dapat memenuhi persyaratan standar yang ditetapkan oleh Kementerian Kelautan dan Perikanan (KKP) (Direktorat Jenderal Perikanan Budidaya/DJPB, 2013) yang mempersyaratkan bahwa vaksin ikan yang dianggap efektif harus memiliki nilai RPS $\geq 50 \%$ apabila diberikan melalui perendaman.

Penggunaan vaksin "trivalen" oleh pembudidaya ikan, masih perlu dilengkapi dengan persyaratan teknis lainnya agar memenuhi standar sediaan obat ikan 
Tabel 3. Mortalitas (\% ikan uji dan nilai relative percentage of survival (RPS) setelah diuji tantang terhadap bakteri penyebab penyakit pada ikan lele, nila, dan gurami

Table 3. Mortality (\%) of fish and the value of relative percentage of survival (RPS) after challenged against bacteria causing diseases on African catfish, tilapia, and giant gourami.

\begin{tabular}{|c|c|c|c|c|c|}
\hline $\begin{array}{c}\text { Ikan } \\
\text { Fish species }\end{array}$ & $\begin{array}{l}\text { Diuji tantang terhadap } \\
\text { Challenge against }\end{array}$ & & $\begin{array}{l}\text { Perlakuan } \\
\text { Treatments }\end{array}$ & $\begin{array}{l}\text { Mortalitas } \\
\text { Mortality }(\%)\end{array}$ & $\begin{array}{c}\text { Relative percentage } \\
\text { survival (RPS) }\end{array}$ \\
\hline \multirow{5}{*}{$\begin{array}{l}\text { Lele } \\
\text { African catfish }\end{array}$} & \multirow{5}{*}{$\begin{array}{c}\text { Aeromonas } \\
\text { hydrophila-AHL0905-2 }\end{array}$} & $A$ & Rendam (Immersion ) & $53.34 \pm 6.67$ & 45.50 \\
\hline & & $\mathrm{B}$ & Pakan (Oral) & $66.67 \pm 10.18$ & 31.80 \\
\hline & & $\mathrm{C}$ & Rendam + booster (Immersion + booster $)$ & $24.47 \pm 3.85$ & 75.00 \\
\hline & & $\mathrm{D}$ & Pakan + booster (Oral + booster ) & $31.13 \pm 3.85$ & 68.20 \\
\hline & & $E$ & Kontrol (Control) & $97.80 \pm 3.85$ & - \\
\hline \multirow{5}{*}{$\begin{array}{l}\text { Nila } \\
\text { Tilapia }\end{array}$} & \multirow{5}{*}{$\begin{array}{c}\text { Streptococcus } \\
\text { agalactiae N14G }\end{array}$} & $A$ & Rendam (Immersion ) & $42.22 \pm 10.18$ & 42.40 \\
\hline & & $\mathrm{B}$ & Pakan (Oral) & $53.33 \pm 6.67$ & 27.30 \\
\hline & & $\mathrm{C}$ & Rendam + booster (Immersion + booster ) & $33.33 \pm 6.67$ & 54.50 \\
\hline & & $\mathrm{D}$ & Pakan + booster (Oral + booster ) & $44.44 \pm 7.70$ & 39.40 \\
\hline & & $E$ & Kontrol (Control) & $73.33 \pm 6.67$ & - \\
\hline \multirow{5}{*}{$\begin{array}{l}\text { Gurami } \\
\text { Giant gourami }\end{array}$} & \multirow{5}{*}{$\begin{array}{c}\text { Aeromonas } \\
\text { hydrophila-AHL0905-2 }\end{array}$} & $A$ & Rendam (Immersion ) & $37.80 \pm 7.70$ & 55.20 \\
\hline & & $\mathrm{B}$ & Pakan (Oral) & $42.22 \pm 10.18$ & 50.00 \\
\hline & & $\mathrm{C}$ & Rendam + booster (Immersion + booster ) & $31.11 \pm 10.18$ & 63.20 \\
\hline & & $\mathrm{D}$ & Pakan + booster (Oral + booster ) & $40.00 \pm 6.67$ & 52.60 \\
\hline & & $\mathrm{E}$ & Kontrol (Control) & $84.44 \pm 7.70$ & - \\
\hline \multirow{5}{*}{$\begin{array}{l}\text { Gurami } \\
\text { Giant gourami }\end{array}$} & \multirow{5}{*}{$\begin{array}{l}\text { Mycobacterium } \\
\text { fortuitum } 31\end{array}$} & $A$ & Rendam (Immersion ) & $44.44 \pm 3.85$ & 41.20 \\
\hline & & $\mathrm{B}$ & Pakan (Oral) & $48.89 \pm 7.70$ & 35.30 \\
\hline & & $\mathrm{C}$ & Rendam + booster (Immersion + booster ) & $31.11 \pm 7.70$ & 58.80 \\
\hline & & $\mathrm{D}$ & Pakan + booster (Oral + booster ) & $40.00 \pm 6.67$ & 47.10 \\
\hline & & $E$ & Kontrol (Control) & $75.56 \pm 10.18$ & - \\
\hline
\end{tabular}

(nomor registrasi) dari KKP yang mengharuskan lulus uji mutu, di antaranya adalah performa hasil uji multilokasi, keamanan, sterilitas, dan stabilitas vaksin.

\section{KESIMPULAN}

Vaksin trivalen mampu menginduksi kekebalan spesifik (antibodi) dalam tubuh ikan secara sinergis, dan dapat digunakan untuk mencegah tiga jenis penyakit secara simultan; yaitu: motile aeromonas septicemia (MAS), streptococcosis, dan mycobacteriosis pada budidaya ikan air tawar. Nilai RPS vaksin trivalen sebesar $\geq 50 \%$ pada penelitian ini, secara keseluruhan hanya dicapai apabila diaplikasikan melalui perendaman + booster. Oleh karena itu, metode aplikasi tersebut menjadi salah satu persyaratan teknis pada penggunaan sediaan vaksin trivalen.

\section{UCAPAN TERIMA KASIH}

Penelitian ini dibiayai oleh DIPA 2016 Balai Riset Perikanan Budidaya Air Tawar dan Penyuluhan Perikanan (BRPBATPP), Bogor. Penulis mengucapkan terima kasih kepada Saudara Ahmad Wahyudi, Setiadi, Edy Farid
Wadjdy, dan Johan Afandi atas bantuannya selama pelaksanaan kegiatan penelitian.

\section{DAFTAR ACUAN}

Amend, D.F. (1981). Potency testing of fish vaccines. Development Biological Standard, 49, 447-454.

Bangkit, I. (2011). Efektivitas vaksin Mycobacterium Fortuitum yang diinaktivasi dengan formalin untuk pencegahan mycobacteriosis pada ikan gurami (Osphronemus goramy). Skripsi. Jurusan Perikanan, Fakultas Perikanan dan Kelautan, Universitas Padjadjaran, Jatinangor. Bandung, $58 \mathrm{hlm}$.

Direktorat Jenderal Perikanan Budidaya. (2013). Pengujian mutu obat ikan golongan biologik dalam metode pengujian mutu dan obat ikan untuk mendapatkan nomor registrasi dari Kementerian Kelautan dan Perikanan. Direktorat Jenderal Perikanan Budidaya (tidak dipublikasikan).

Gudding, R., \& Goodrich, T. (2014). The history of fish vaccination in fish vaccination. Gudding, R., Lillehaug, A., \& Evensen, O. (Eds.). John Wiley \& Sons, Ltd. Wiley Blackwell, p. 1-9. 
Huang, Z., Tang, J., Li, M., Fu, Y., Dong, C., Zhong, J.F., \& He, J. (2012). Immunological evaluation of Vibrio alginolyticus, Vibrio harveyi, Vibrio vulnificus and Infectious Spleen and Kidney Necrosis Virus (ISKNV) combined-vaccine efficacy in Epinephelus coioides. Veterinary Immunology and Immunopathology, 150, 61-68.

Katz, D.S. (2011). Bacterial agglutination protocol. Microbe Laboratory. American Society for M icrobiology, $13 \mathrm{pp}$.

Li, L.P., Wang, R., Liang, W.W., Huang, T., Huang, Y., Luo, F.G., Lei, A.Y., Gan, X., \& Chen, M. (2015). Development of live attenuated Streptococcus agalactiae vaccine for tilapia via continuous passage in vitro. Fish and Shellfish Immunology, 45(2), 955-963.

Maskur, Hastuti, M.S., Taukhid, Lusiastuti, A.M., Sugiani, D., \& Nurzain, M. (2014). Buku saku pengendalian hama dan penyakit ikan. Direktorat Kesehatan Ikan dan Lingkungan, Direktorat Jenderal Perikanan Budidaya. $216 \mathrm{hlm}$.

Park, S.B., Nho, S.W., Jang, H.B., Cha, I.S., Kim, M.S., Jai Lee, W., \& Jung, T.S. (2016). Development of three-valent against streptococcal infections in olive flounder, Paralichthys olivaceus. Aquaculture, 461, 25-31.

Roberson, B.S. (1990). Bacterial agglutination. In Fish immunology technical communication No. 1. Stolen, J.S., Fletcher, T.C., Anderson, D.P., Roberson, B.S., \& van Muiswinkel, W.B. (Eds.). SOS Publications. Fair Haven, N.J., 197 pp.

Taukhid, Supriyadi, H., Komarudin, O., \& Sugiani, D. (2011). Vaksin Aeromonas hydrophila. Republik Indonesia. Nomor Paten P002011 00092.

Taukhid, Taslihan, A., \& Lusiastuti, A.M. (2012a). Prospek vaksinasi pada perikanan budidaya di Indonesia. Prosiding Indoaqua-Forum Inovasi Teknologi Akuakultur, hlm. 805-814.

Taukhid, Lusiastuti, A.M., Sugiani, D., Sumiati, T., \& Purwaningsih, U. (2012b). Vaksin ikan Streptovac. Republik Indonesia. Nomor Paten P00201200598.
Taukhid, Lusiastuti, A.M., Purwaningsih, U., Sugiani, D., \& Sumiati, T. (2014a). Aplikasi vaksin mycofortivac untuk pencegahan penyakit mycobacteriosis pada budidaya ikan gurami. Rekomendasi Teknologi Kelautan dan Perikanan 2014. Badan Penelitian dan Pengembangan Kelautan dan Perikanan. Jakarta, hlm. 211-219.

Taukhid, Lusiastuti, A.M., Sumiati, T., Sugiani, D., \& Purwaningsih, U. (2014b). Pengembangan vaksin bivalen untuk pencegahan penyakit motile aeromonas septicemia (MAS) dan streptococcosis pada ikan nila (Oreochromis niloticus). Prosiding Seminar Hasil Penelitian Terbaik Tahun 2014. Badan Penelitian dan Pengembangan Kelautan dan Perikanan. Jakarta, hlm. 1-18.

Taukhid, Sumiati, T., Andrianto, S., \& Gardenia, L. (2014c). Evaluasi pascarilis vaksin bakteri in-aktif Aeromonas hydrophila (Hydrovac) dan Streptococcus agalactiae (Streptovac) untuk pencegahan penyakit motile aeromonas septicemia (MAS) dan streptococcosis pada budidaya ikan air tawar. Seminar Hasil Riset BPPBAT Bogor.

Taukhid, Lusiastuti, A.M., Purwaningsih, U., Sugiani, D., \& Sumiati, T. (2014d). Vaksin Mycobacterium fortuitum. Republik Indonesia. Nomor Paten P00201401523.

Taukhid, Purwaningsih, U., Sugiani, D., Sumiati, T., \& Lusiastuti, A.M. (2015). Efikasi vaksin in-aktif bakteri Aeromonas hydrophila-AHL0905-2 (Hydrovac) dan Streptococcus agalactiae N14G (Streptovac) untuk pencegahan penyakit bakterial pada budidaya ikan air tawar. Jurnal Riset Akuakultur, 10(4), 541-551.

Taukhid, Gardenia, L., \& Andriyanto, S. (2016). Efikasi vaksin "trivalen" (Aeromonas hydrophila, Streptococcus agalactiae, dan Mycobacterium fortuitum) untuk pencegahan penyakit bakteri potensial pada budidaya ikan air tawar. Jurnal Riset Akuakultur, 11(4), 373-385. 